\title{
O caráter inteligível como fundamento ontológico para a sabedoria de vida*
}

\author{
Le caractère intelligible comme fondement ontologique de la \\ sagesse de la vie
}

\author{
Dax Moraes \\ Professor do Departamento de Filosofia e do PPGFIL da Universidade \\ Federal do Rio Grande do Norte (UFRN) \\ E-mail: oejeblik@gmail.com
}

\begin{abstract}
Resumo: Exponho no presente artigo uma breve argumentação pela consideração da Ontologia como chave para a compreensão do fundamento da sabedoria de vida, ou seja, o caráter inteligível como condição ontológica do caráter adquirido. Nesse sentido, distinguindo o sentimento que pode conduzir à moralidade da experi-ência refletida que pode produzir no in-divíduo o conhecimento de seu próprio ser, ou vontade, chego ao que pode ser uma elucidação da diferença essencial entre o asceta e o sábio, bem como do fato de suas ações serem independentes de toda Ética.
\end{abstract}

Palavras-chave: Caráter inteligível; Caráter adquirido; Sabedoria de vida.
Abstract: Dans cet article je présente un tout bref argument pour la consideration de l'Onto-logie en tant que clef pour la compréhension du fondement de la sagesse de la vie, c'est-à-dire, le caractère intelligible comme condition ontologi-que du caractère acquis. À ce propos, en faisant distintion entre le sentiment qui peut conduire à la moralité et l'expérience réfléchie qui peut produire dans l'individu la conaissance de son propre être, dit-on, sa propre volonté, j'arrive à ce qui est peutêtre une éclairement de la diffé-rence essentielle entre l'ascète e le sage, ainsi que le fait que leurs actions soient indépendants de toute Éthique.

Keywords: Caractère intelligible; Carac-tère acquis; Sagesse de la vie.

\footnotetext{
* Conferência apresentada durante o VII Colóquio Internacional Schopenhauer, ocorrido na Universidade Federal da Bahia (UFBA), em Salvador, de 26 a 30 de outubro de 2015.
} 
I

nicio minhas breves considerações recordando as últimas palavras de Schopenhauer no último capítulo do segundo volume de $O$ mundo como vontade e representação (MVR), intitulado "Epifilosofia":

[...] o ato da Vontade, a partir do qual surge o mundo, é o nosso próprio ato. Ele é livre, pois o princípio da razão suficiente, único a partir do qual toda necessidade adquire o seu significado, é apenas a forma da aparência fenomênica da vontade. Só por esse motivo, essa aparência fenomenal, quando existe, é absolutamente necessária em seu curso. Só por isso podemos reconhecer a partir do fenômeno da natureza o ato da Vontade e, de acordo com isto, eventualiter querer outra coisa ${ }^{1}$.

Subjaz à presente exposição um questionamento acerca dos limites inerentes a classificações valorativas tais como "pessimismo metafísico" e "otimismo prático" no que tange a uma filosofia cuja exaustiva exposição se encerra em uma síntese não-dualista. Seriam também, metafísica e prática, duas perspectivas sobre o mesmo? A vida sob um duplo olhar - o universal e o particular? Não me parece algo tão simples...

Como toda ação individual é necessária e tal necessidade remete à vontade determinada como caráter inteligível - mas tal necessidade é necessidade apenas à luz do princípio de razão -, de maneira que cada indivíduo - na exclusiva condição de fenômeno espaço-temporal - exprime na ação seu modo de ser, a sabedoria de vida e suas possibilidades de efetivação se inserem em um universo mais amplo que devemos levar em consideração a fim de situá-las adequadamente umas em relação às outras. Afinal, tratar isoladamente fenômenos diversos do que é em si mesmo uno pode nos levar a extravios dualistas. Neste percurso, parece, então, cabível estabelecer com clareza, embora sumariamente, algumas distinções, considerando que o quarto livro do MVR aborda uma série de assuntos que, do próprio ponto de vista de seu autor, sofrivelmente caberiam todos sob o título "Ética", considerada em sentido estrito. Aliás, pode-se sugerir que essa diversidade de assuntos culmina precisamente em tornar claro o que pertence à Ética propriamente dita e o que se insere apenas no quadro mais genérico de temas correlatos, relativos ao modo de ser para consigo mesmo e em meio aos outros.

${ }^{1}$ SCHOPENHAUER, A. MVR II(2), 50, p. 391. 
Considero pressuposto que, para Schopenhauer, não há algo como "filosofia prática", apenas "prática de vida" e um saber bastante concreto a seu respeito. "Saber", diz Schopenhauer no § 10 do MVR, "é a consciência abstrata, o ter-fixo em conceitos da razão aquilo que foi conhecido em geral de outra maneira"2, constituindo-se de juízos verdadeiros cujo fundamento é intuitivo, realª . Juízos destituídos de fundamento não constituem saber propriamente dito. Os saberes relativos à vida e à moral recebem formulação abstrata, podendo-se erigir uma filosofia sobre a prática, dogmas religiosos ou máximas, mas o cerne da distinção que proponho reside nos respectivos objetos desses saberes em diferentes âmbitos de realização.

\section{Compaixão e virtude}

Em primeiro lugar, no topo da escala, temos uma moral universal, que consiste na contenção do movimento afirmador da vontade própria dentro dos limites de sua expressividade fenomênica, a saber, o próprio corpo. Trata-se do caráter negativo da moralidade expresso na máxima de "não se prejudicar a outrem". Contudo, segundo a doutrina da unidade da Vontade, Schopenhauer é consistente ao perceber que a mera sobrevivência também depende de que o indivíduo se afirme sobre os fenômenos exteriores ao próprio corpo. Exemplo cabal disto é a alimentação - é absolutamente impossível ao indivíduo sobreviver sem estar simultaneamente consumindo outros fenômenos individuais da Vontade, incorporando a força vital alheia à sua própria; abster-se de carne animal é mero paliativo na medida em que reduz o sofrimento no mundo, mas o problema não se resolveria ainda que nos alimentássemos de minerais in natura ou sintetizados em laboratório. Apenas as plantas o fazem, mas apenas os minerais subsistem por si mesmos. A reprodução é também o mesmo querer afirmando-se em um novo indivíduo, e novamente apenas os minerais cumprem o ideal de se manterem dentro de seus limites. Portanto, não basta a mera contenção do movimento afirmador - esse movimento deve retroceder, negar a si mesmo, "querer outra coisa" que não a vida. Entre os extremos, há uma gradação potencialmente infinita.

\footnotetext{
${ }^{2}$ SCHOPENHAUER, A. MVR I, § 10, p. 100.

${ }^{3}$ V. idem, ibidem, p. 99.
} 
Em certo sentido, há aí uma concepção bastante pobre e ao mesmo tempo insolitamente radical de "liberdade", negativamente expressa por "não precisar de nada". Mas seria a pedra mais livre do que o asceta? Quem ousaria dizê-lo? Que liberdade haveria no nada-fazer? Uma "liberdade ontológica", decerto, entendida como livre determinação para existir, mas desde então perdida para a vontade incapaz da autonegação e perpetuamente encerrada na matéria bruta. Deixe-se, portanto, de lado a pedra...

A moral universal a que me referi pode ser abstratamente expressa em princípios, mas Schopenhauer insiste em sua polêmica dizendo que nenhum princípio ou ajuizamento produz o agir moral, senão em aparência. Pode-se ver transparecer algo da distinção kantiana entre o agir por e o agir conforme a moralidade - dispensemo-nos de falar em "dever" para irmos direto ao ponto. Essa distinção é importante, pois a mera conformidade, mesmo (e ordinariamente) apoiada no egoísmo natural em que se sustenta o Estado, é pragmaticamente válida e desejável na esfera pública de que trata o Direito. Este é o campo próprio para máximas e leis, bem como para que a educação desempenhe seu papel. Nada disso, porém, "produz virtude" ou "bom caráter". Até aqui, tudo concorda com Kant, mas Lefranc vai ao núcleo da polêmica desdobrada em Sobre o fundamento da moral ao dizer que a "filosofia moral imperativa confunde o fundamento da moral com seu princípio"4. Acontece, porém, que Schopenhauer não simplesmente substitui o princípio pelo fundamento, tampouco apenas estabelece um fundamento anterior ao princípio após distingui-los, desfazendo a "confusão" estabelecida na filosofia crítica kantiana. A compreensão mesma de "princípio" é distinta em Kant e Schopenhauer, de modo que se produza o aspecto mais ríspido do embate.

O princípio kantiano de todo agir, para permanecer no interior dos limites legais do pensamento, por analogia com os princípios do conhecimento, é uma causa, o que fica evidente logo no início da terceira seção de sua Fundamentação da metafísica dos costumes 5 . Deve-se observar e admitir, todavia, que Schopenhauer

\footnotetext{
${ }^{4}$ LEFRANC, J. Compreender Schopenhauer, p. 153.

${ }^{5}$ KANT, I. Fundamentação da metafísica dos costumes, BA 97-98, p. 93-94. V. tb. BA 126, p. 115: “[...] a razão em relação com um mundo puro inteligível como causa possível eficiente, isto é, como causa determinante da vontade [...]". Esse problema é abordado com mais detalhamento em: MORAES, D. O dualismo kantiano e sua crítica por Schopenhauer: considerações acerca do caráter analógico da filosofia prática e suas limitações, p. 411-447.
} 
abraça a proposta kantiana, expressa no prefácio da mesma obra, de que a ação moral não se determina segundo meios e fins, mas segundo seu princípio, pois a fundamentação (Grundlegung) kantiana, conforme o próprio Kant, "nada mais é [...] do que a busca e fixação do princípio supremo da moralidade"6. Mas é justamente a fixidez de um solo (Grund) o que não oferece nem pode oferecer um princípio meramente pensável, que não consistiria senão em uma "bolha de sabão"7, bela, porém vazia e efêmera. 0 fundamento (Grund) não pode, portanto, ser abstrato, mas concreto; não um pensamento, mas um sentimento - não um "respeito"... uma compaixão. Poder-se-ia formular livremente a compaixão, em um primeiro estágio, como um sentimento segundo o qual se consente a existência do outro, fundamento de toda justiça autêntica. Na altura da metade do $\S 55$ do MVR, pouco antes de tratar do arrependimento, Schopenhauer diz:

[...] para que a proporção existente num dado homem entre egoísmo e compaixão possa entrar em cena, não é suficiente que possua riqueza e veja a miséria alheia: também tem de saber o que é permitido fazer com a riqueza, tanto para si quanto para os outros; ademais não apenas tem de ter sido apresentado ao sofrimento alheio, mas também tem de ter experimentado o que é o sofrimento, bem como o prazer8.

Por isso quem antes agia de modo indiferente pode vir a agir de modo justo, e o egoísta natural pode, mediante um sentimento até então desconhecido, encontrar em si uma disposição boa, compassiva, sem que isto denote alteração em seu caráter. Até então lhe faltava motivação concreta para a caridade, capaz de movê-lo positivamente a socorrer o outro por amor dele e não de si mesmo. Sobre o caráter, retornarei adiante. Por ora, ocupemo-nos do seguinte: o sentimento é capaz de promover um conhecimento cuja expressão em ações vai além da mera legalidade no convívio civil, no qual mesmo o exemplo e uma "ética da melhoria", "aclarando a cabeça", são meros substitutos para a força das autoridades. Seguindo Rousseau, para quem a moralidade reside no ato de vontade, não por força ou por prudência ${ }^{10}$, Schopenhauer exige para a moralidade um solo firme: a

\footnotetext{
${ }^{6}$ Idem, ibidem, BA XV, p. 19.

${ }^{7}$ SCHOPENHAUER, A. M, § 14, p. 124.

${ }^{8}$ SCHOPENHAUER, A. MVR I, § 55, p. 382.

${ }^{9}$ V. SCHOPENHAUER, A. M, § 20, p. 198-199.

${ }^{10}$ ROUSSEAU, J.-J. Do contrato social, livro I, cap. III, p. 59.
} 
concretude mais imediata de um sentimento. A universalidade do saber moral é, dito brevemente, meramente abstrata, tendo sua eficácia limitada ao âmbito da exterioridade. Portanto, seu pertencimento à "Ética" apenas se dá na condição de pertinência ao mundo dos costumes.

A ação propriamente boa desde seu fundamento é sempre individual e, uma vez que tal fundamento é um sentimento, conclui-se que seja, em si mesma, nãoracional; não um saber, mas um mistério, pois seu conceito se determina por exclusão ${ }^{11}$. 0 trecho acima citado do $\$ 55$ do MVR ainda nos diz que, no convívio ordinário, há sempre uma mescla de motivações morais e não-morais, pois em geral a vontade não se nega, apenas contém seu movimento afirmador, podendo nisto estar seguindo em maior ou menor medida seus próprios interesses. Em geral, portanto, ações morais são atos isolados de justiça e caridade praticadas de boa vontade - ou de "bom coração", como prefere dizer Schopenhauer. Todavia, algo distinto se dá quando a compaixão emerge de uma consciência ontológica mais clara e radical, de um conhecimento, por assim dizer, originário.

\section{Compaixão e ascetismo}

Sempre que Schopenhauer fala em justiça e virtudes assemelhadas, dá a entender que há um conhecimento inconsciente de que ferir o outro é ferir a si mesmo em essência, de que negar a vontade do outro mediante a autoafirmação sobre ele é ao mesmo tempo negar a própria afirmação em outro, de modo a dizer que a vontade está "mordendo sua própria carne". O conflito interno da Vontade é, portanto, o fato de que seus fenômenos ferem a si mesmos enquanto lhes parece ferir a outrem, encerrados que estão na visão do mundo segundo o princípio de individuação. Desse modo, a Vontade é indiferente ao indivíduo na medida em que, do ponto de vista universal, afirmação e negação neutralizam-se no mesmo ato de vontade - a isso Schopenhauer chama "justiça eterna", brevemente aludida no final do $\S 60$ e tematizada no $\S 63$ do MVR. Sem prejuízo para a tese de que a compaixão seja o fundamento da moral, quando a unidade radical da Vontade se torna conhecida e emerge à consciência a universalidade do sofrimento, a vontade

${ }^{11}$ V. SCHOPENHAUER, A. MVR I, § 11, p. 100. 
descobre, por exemplo, que o pobre não é poupado pela caridade, que a ajuda ao outro não o salva, que a recusa ao uso do próprio poder apenas empodera o outro de maneira deficiente. 0 remédio para as dores do mundo é a completa supressão de todo movimento afirmador. A luta universal da Vontade contra si mesma permanece em meu próprio corpo mesmo enquanto jejuo, pois meu corpo se mantém vivo consumindo a si mesmo, suas próprias reservas de energia, e mesmo após a minha morte, micro-organismos continuarão consumindo a carne que restou e, no fundo da terra, alimentarão a planta que germinará, e esta o animal, repetindo-se o ciclo irrefreável da vida. Em suma, nenhuma ação há de salvar o mundo e a vida ética mesma possui suas limitações incontornáveis.

Se, por um lado, o asceta atinge a perfeição moral - a santidade - na medida em que experimenta a verdade do mundo em sua plenitude, por outro, sabe que a moralidade só se aplica ao que concerne à sua relação com os outros. Com relação a si mesmo, a atitude é outra, pois se dirige ao seu próprio ser. Para consigo mesmo, o asceta é injusto e recebe a injustiça de bom grado ${ }^{12}$. Por estranho que isto possa parecer à primeira vista, é notável o que diz Schopenhauer sobre a transição da virtude à ascese no $§ 68$ do MVR:

[...] não mais adianta amar os outros como a si mesmo, por eles fazer tanto, como se fosse a si, mas nasce uma repulsa pela Vontade de vida, núcleo e essência de um mundo reconhecido como povoado de penúrias. Renega, por conseguinte, precisamente essa essência que nele aparece expressa já em seu corpo. Essencialmente fenômeno da Vontade, ele cessa de querer algo, evita atar sua vontade a alguma coisa, procura estabelecer em si a grande indiferença por tudo ${ }^{13}$.

Essa indiferença (Gleichgültigkeit) quer dizer, de modo nu e cru: tudo vale o mesmo. A rigor, para aquele que ultrapassou a multiplicidade fenomênica, não há um "si mesmo", tampouco um "outro". O "tu és isto" dá lugar a "o mundo é uma só vontade". Eu e não-eu se dissolveram e perderam a concretude ontológica de uma "autoconsciência". Nesse estágio, que lugar haveria para "amar o outro em sua essência". Toda ética se defronta com seu limite incontornável, de modo extremo, a saber: sua exclusiva aplicabilidade ao mundo como representação. Nesse contexto,

${ }^{12}$ Cf. idem, ibidem, $\S 68$, p. 484-485.

${ }^{13}$ Idem, ibidem, p. 482-483. 
é melhor fazer o bem do que não fazê-lo, mas isso só se aplica à vida "exterior". 0 asceta, cujo interior e exterior colapsaram, conduzido pela experiência do fundamento ontológico da moralidade em seu grau máximo, superou a própria moralidade pela vivência da compaixão, sentiu a dor universal de viver e não pode mais querê-la, nem para si nem para ninguém. 0 asceta transcendeu para além do bem e do mal pertinentes ao mundo, cujo valor é reciprocamente relativo.

\section{A sabedoria de vida}

Vimos que a compaixão, na condição de fundamento da moral, assume diferentes graus de expressão, que vão desde uma conformação do caráter a um bem comum até um espontâneo fazer o bem sem ver a quem, absolutamente incondicional, independente da lei ou do hábito. Contudo, isso sempre remete ao modo de ação para com os outros. No que concerne às ações para consigo mesmo, encontramos um modo de ser à parte do domínio da moral, muito embora relacionado com ela segundo o fundamento e certamente importante para a realização da moralidade no contexto da vida em comum. A sabedoria de vida é uma alternativa para se regular uma conduta para consigo mesmo, valendo estabelecer um paralelo entre o sábio e o asceta. Assim como o asceta, segundo procurei mostrar, supera a moral e não mais precisa dela, o sábio descobre uma conduta que diz respeito, antes de tudo, a seu próprio bem-estar, ao contrário, porém, do asceta que busca o próprio mal. Enquanto o asceta supera o princípio de individuação, o sábio encontra a justa medida para ser um indivíduo menos infeliz, pois descobriu em que consiste seu sofrimento: a inadequação insuperável entre o que deseja e o que pode efetivar. 0 empenho aqui não é o de negar a vida, mas o de harmonizar-se com ela.

Gostaria de observar que o diagnóstico pessimista de que "tudo é dor" perde todo seu significado para aquele que ultrapassou a percepção do mundo como multiplicidade em luta, para aquele em cujo conhecimento se dissolveu toda diferença entre eu e não-eu. Enquanto pronunciada por um fenômeno individual da Vontade, a sentença "tudo é dor" é meramente relativa, uma representação que serve de motivo ou razão para a negação do querer-viver, pois, segundo ela, tudo é 
inútil. Toda a retórica schopenhaueriana assume esse posicionamento, é verdade. Do ponto de vista da Vontade ela-mesma, porém, nada é real: nem esse sofrimento, nem essa alegria. Isso é importante porque a razão não é apta para representar adequadamente, sem paradoxo, a verdade de que "tudo é um". A literatura búdica que tenta fazê-lo, o faz precisamente por meio de paradoxos do tipo "Este que trilha o caminho não é este que trilha o caminho". Por isso, a via do argumento pessimista é a única capaz de servir ao mesmo tempo como quietivo, só ela é compatível com a indiferença ontológica radical, exprimindo uma espécie de "nada resta a fazer pela vida". Ainda assim, segundo os budistas, até mesmo esse derradeiro motivo deve ser abandonado: aquele que deseja a Iluminação só a alcança quando não mais a deseja; enquanto tem consciência de que a alcançou, não a alcançou, mas é uma consciência que pensa tê-la alcançado. O Buda que conhece não é mais o Buda; ao conhecer, já deixou de ser "o Buda”. Do ponto de vista do em-si, haver ou não haver dor é absolutamente irrelevante, e somente então o mundo dá lugar à paz do Nirvana, que, aliás, é paz e não é paz. A dor só é dor para a consciência que a sente.

A sabedoria de vida, por sua vez, não é decorrente de um conhecimento da mesma espécie, puro e imediato, mas da experiência vivida. Envolve ou pressupõe reflexão e, pode-se dizer, autocrítica - ou melhor: lucidez. Trata-se do uso da razão não para produção de motivos abstratos e renovados objetos de desejo, mas para o esclarecimento da vontade acerca do que ela quer e pode efetivar. Mas não se pode pensar que Schopenhauer advogue um aprimoramento do caráter pela razão, nem mesmo pelo sentimento. Os diferentes graus da compaixão dependem das experiências do sentimento e suas interações como motivos com o caráter do indivíduo. Dito de outro modo, a compaixão é sempre uma possibilidade do caráter. A sabedoria de vida não o será menos. Esta última se relaciona àquela retração do movimento de afirmação da vontade, mas apenas no mundo particular, ou seja, no que tange à equação entre o que desejo e o que posso obter segundo minhas forças, segundo meu caráter, ou meu ser determinado, pois o que posso é desde sempre o grau determinado em que a vontade se determina como o indivíduo que sou. 0 alvo do ascetismo é a supressão do caráter pela negação do querer-viver que nele se determinou, ao passo que a sabedoria de vida consiste na aquisição de um caráter, ou seja, no viver segundo o modo como o querer-viver é determinado como a 
pessoa que sou. Portanto, não está ao meu alcance ser diferente do que sou, não havendo qualquer espaço para esperanças do tipo "sofrerei menos se aprender quem realmente sou", pois as possibilidades de aprender já se encontram determinadas segundo a intensidade com a qual meu caráter adere aos objetos de desejo oferecidos pelo intelecto, o grau de obstinação com que meu caráter se impõe sobre todo o resto em vista de satisfazer suas carências intrínsecas. Não há de se apontar aí um conformismo, pois agir segundo o que se é elimina a tensão inerente a todo mero conformar-se e "tolerar", ou seja, a todo assumir a forma de algo em que não se reconhece ou permitir o que intimamente se rejeita. Conformamo-nos ao que nos é estranho e exterior e toleramos o que não quereríamos para nós mesmos; quanto ao que nos é próprio, resta-nos apenas assumi-lo como tal.

Em suma, a possibilidade de um bem-estar consigo mesmo depende da constatação de que nada há a fazer para a transformação daquilo que somos. Podemos (e devemos) nos esforçar para a aquisição de uma lucidez sobre o mundo e nós mesmos, sobre a necessidade que rege tudo no mundo, mas o efeito desse saber sobre nossa efetiva satisfação, para que jamais pensemos em retrospecto "Eu deveria ter ao menos tentado..., não pode ser senão indireto e pouco provável. Tal possibilidade não nos permite um otimismo, pois o otimismo pode nos mover a tentar e o fracasso nas tentativas produz fenômenos como o do piedoso que, como o próprio Jó, perde a paciência com a indiferença de Deus, assim como a Vontade é, por sua própria "natureza", indiferente a cada um de nós. A sabedoria de vida nos mostra que estamos sós e sem ter a quem recorrer. "Não alimentar esperanças." "Não ter nostalgia do passado." "Não se ocupar previamente com o que não é iminente nem com a morte." "Não cometer sacrifícios ou se inquietar em nome do próprio bem-estar." Não seriam estas algumas de suas máximas? Ainda assim, como vimos, servem meramente ao esclarecimento. Enquanto não somos capazes de assumir o nosso próprio ser, sim, sentimo-nos como que forçados, como devendo nos conformar àquilo que sabemos sobre nós mesmos, mas ainda parece para nós uma dubitável opinião de terceiros, tema ao qual retornarei em breve.

Deve-se evitar cair no erro daqueles que, lançando mão disso para acusar Schopenhauer até mesmo de charlatanismo, dizem, como Russell, que o "evangelho 
da resignação [...] não é muito coerente nem muito sincero", fornecendo exemplos dessa "insinceridade"14. A isto Schopenhauer já antecipara uma resposta, dizendo, por exemplo: “é tão pouco necessário o santo ser um filósofo quanto o filósofo ser um santo; [...] é uma estranha exigência feita a um moralista a de que ele não deve recomendar outra virtude senão a possuída por ele mesmo"15. A estranheza de semelhante exigência fica bastante clara em casos como o de Sade, que não hesita em propor a universalização da "natureza criminosa", ou de qualquer outro que pretenda que todos sigam os seus caprichos a fim de não encontrar obstáculos para si mesmo. Ora, não se pode sequer dizer que Schopenhauer chega a ser um pregador de má-fé, do tipo, "Façam o que digo, não façam o que eu faço; sou um mau exemplo, afinal, porém sábio". A má-fé, pelo contrário, se encontra naqueles que o acusam, como se dissessem: "Se tu mesmo não o fazes; por que haveria eu de fazer?!". Trata-se de, indiretamente, buscar autoindulgência nos erros alheios, atitude inequivocamente imoral. Isto, o sábio não faz, pois sabe ser responsável por si mesmo: seu caráter é inalienável. Nisto se funda toda moderação no que nos cabe exigir de outrem, expressa por Schopenhauer em trecho decisivo do $§ 55$ do MVR, que reúne questões centrais do seu pensamento:

Velle non discitur [Querer não se aprende]. Assim como só pela experiência nos tornamos cônscios da inflexibilidade do caráter alheio e até então acreditávamos de modo pueril poder através de representações abstratas, pedidos e súplicas, exemplos e nobreza de caráter fazê-lo abandonar seu caminho, mudar seu modo de agir, despedir-se de seu modo de pensar, ou até mesmo ampliar suas capacidades; assim também conosco. Temos primeiro de aprender pela experiência o que queremos e o que podemos fazer: pois até então não o sabemos, somos sem caráter, e muitas vezes, por meio de duros golpes exteriores, temos de retroceder em nosso caminho. - Mas, se finalmente aprendemos, então alcançamos o que no mundo se chama caráter, o caráter adquirido. Este nada mais é senão o conhecimento mais acabado possível da própria individualidade ${ }^{16}$.

Portanto, enquanto o asceta atinge o conhecimento máximo da Vontade universal, o sábio atinge o conhecimento máximo da vontade singular que ele

\footnotetext{
${ }^{14}$ RUSSELL, B. História da filosofia ocidental, p. 305-306.

${ }^{15}$ SCHOPENHAUER, op. cit., p. 487.

${ }^{16}$ Idem, ibidem, § 55, p. 393-394.
} 
mesmo é. O problema na compreensão do caráter adquirido reside em que ele pode ser inadvertidamente tomado como uma mudança em relação ao caráter empírico que venha simplesmente substituí-lo ou, ainda, como algo independente dele, mas não se trata disso, tampouco de que se aprenda a querer diferentemente - querer não se aprende. 0 caráter adquirido depende de ambos os outros e representa uma espécie de "resultante". Não é certamente por acaso que Schopenhauer quase sempre se refira apenas ao caráter inteligível e ao empírico, pois estes sempre se dão, mesmo no indivíduo "sem caráter" e, diria eu, mesmo dentre viventes não-humanos, nos quais o caráter manifesto exprime com menor ruído o caráter da espécie - por isso mesmo vivem melhor, na medida em que não há conflito entre movimento interno e movimento externo do querer, ou tal conflito é muito reduzido. Para se compreender o caráter adquirido, no entanto, não basta tomar como condição exclusiva o fato de o homem ser mais indivíduo do que espécie - isso sequer é suficiente -, mas o que nisso se encontra implicado pelo fato decisivo de que o homem é dotado de uma faculdade produtora de abstrações que o capacita a refletir, graças à qual o próprio indivíduo se reconhece como tal.

O sábio exercita a adequação do desejo ao caráter, e suas ações desde então continuam pertencendo ao caráter empírico, com a diferença de que o caráter inteligível se revela aí de modo mais fidedigno, isto é, menos turbado pelas falsas representações acerca de si mesmo. 0 querer que nos determina desde o começo da existência é inalterável. Inato, é meramente inteligível - não é outra coisa senão a vontade autodeterminada de que todo indivíduo já sempre é fenômeno pensada segundo as experiências que se tem com os outros e consigo mesmo no mundo. 0 caráter empírico, sua expressão no tempo e no espaço segundo a interação do caráter inteligível e motivos dados no mundo, manifesto por cada indivíduo desde que vem ao mundo, realiza-se a cada vez na ação de modo espontâneo até que se deixe orientar por máximas refletidas, não meramente abstratas, mas fundadas no saber lúcido acerca de si mesmo. A experiência de sucessos e fracassos pode nos levar, na medida de nossas capacidades racionais, a uma postura ardilosa, calculista, voltada à satisfação de caprichos, e assim é comumente, desejando o que não podemos obter. Em certos casos, porém, não aprendemos apenas a conhecer e lidar com o mundo dos objetos; aprendemos a conhecer a nós mesmos. Diante 
disso, o sábio deixa de tentar acomodar o mundo a si, não para adequar-se ao mundo, "conformando-se" a forças exteriores, mas sim para adequar-se a si mesmo, reconduzir seu caráter empírico a uma expressão menos ruidosa de seu ser individual. "O conhecimento de nossa mente, com suas faculdades de todo gênero e limites inalteráveis, é, nesse sentido, o caminho mais seguro para obtermos o maior contentamento conosco mesmos"17. Semelhante contentamento consiste precisamente em cessar de desejar o impossível, a fonte dos mais profundos sofrimentos: ser outra pessoa. Eis o que diz belamente Schopenhauer no mesmo lugar. De fato, a vida se torna menos infeliz, mas ainda de modo negativo, pois há de se compreender em que consiste insatisfação e sofrimento: sofrimento é o impedimento de um esforço, que "nasce de uma carência, do descontentamento com o próprio estado"18.

Portanto, na sabedoria de vida, aprende-se a viver de acordo com o que se é e se exprimiu na experiência até então. A ideia de uma eudemonologia, portanto, não tem em si mesma um compromisso direto com a moralidade, cujo alcance é universal, mas com o bem-estar próprio, até porque o egoísmo natural não é imoral em si mesmo. Nas palavras de Schopenhauer, ao fim do $§ 55$ do MVR, o "caráter adquirido [...] é importante não tanto para a ética como para a vida no mundo". Se o asceta supera a moralidade em sua compaixão, prescindindo do mundo graças a um sentimento profundo, o sábio está mais propenso a agir bem com os outros, se não por bondade, ao menos em vista de sua saúde e comodidade, guiado pela razão. Exemplo disso pode ser dado mediante um possível questionamento: "mas como suprimir o esforço e assim evitar ou reduzir o sofrimento se o esforço provém da carência e, se não somos ascetas, somos sempre carentes em alguma medida?". É decisivo para a compreensão do caráter adquirido e da sabedoria de vida como recorrente ao caráter inteligível, que, aqui, não se tem em vista quietivos ou a negação da vontade. A sabedoria em questão é da vida e para a vida. Nesse sentido, não se trata de suspender os movimentos da vontade, mas em oferecer-lhe empenhos adequados. Segundo Schopenhauer, "cada um tem um horizonte próprio daquilo que pode alcançar, e suas pretensões vão até onde vai esse horizonte" e o

${ }^{17}$ Idem, ibidem, p. 395.

${ }^{18}$ Idem, ibidem, § 56, p. 399. 
"que reside além desse horizonte não faz efeito sobre ele"19. Ao invés de o indivíduo exercer seu movimento e empregar seus esforços no exterior, os emprega em si mesmo. Um caráter brando pode exercitar o recolhimento da solidão voluntária, se sua propensão não é a mortificação. Um caráter vigoroso - e isto é mais interessante - pode fazer exercícios físicos, manter o seu corpo em movimento afinado com o movimento da vontade sem com isso fazer mal a quem quer que seja. Aliás, nos Aforismos para a sabedoria de vida, Schopenhauer não se mostra favorável a uma vida sedentária: "uma ausência quase completa do movimento externo" faz surgir "uma desproporção gritante e perniciosa entre a calma exterior e o tumulto interior, pois até o constante movimento interior quer ser apoiado pelo exterior"; até mesmo "as árvores, para prosperar, precisam ser agitadas pelo vento" 20 . Trata-se, portanto, de um adequado emprego de forças naquilo que não causa danos desnecessários nem a si nem a outrem. Do mesmo modo, uma sabedoria de vida não exige a abstenção de carne se se precisa dela para a nutrição, mas desde que na justa medida. A busca por essa medida é o que exige exercício e se mostra para nós como se fosse uma necessidade de conformação. Nas palavras de Schopenhauer:

[...] esse adestramento de si mesmo, resultado de um longo hábito, sempre fará efeito como uma coerção vinda de fora, contra a qual a natureza nunca cessa de resistir, às vezes violando-a inesperadamente. Pois toda ação que segue máximas abstratas se relaciona com a proveniente de uma inclinação originária e inata $[\cdots]^{21}$.

Desse modo, a ontologia entra muito indiretamente na compreensão da sabedoria de vida, em nada contribui para sua aquisição, não sendo sequer necessária sua teorização, como, aliás, de nada serve ao autêntico compassivo e ao autêntico justo, muito embora nos sirva para esclarecer esses últimos casos, ao menos na medida em que se mostrem estranhos ao nosso próprio caráter. Afinal, não é "necessário o santo ser um filósofo". Por essa razão, talvez, os aforismos

\footnotetext{
${ }^{19}$ SCHOPENHAUER, A. Aforismos para a sabedoria de vida, cap. III, p. 50.

${ }^{20}$ Idem, ibidem, cap. II, p. 19.

${ }^{21}$ Idem, ibidem, cap. V, § 30, p. 216.
} 
evocam predominantemente argumentos de cunho psicológico, relativos a nossas representações, independentemente de Schopenhauer pretender ou não formular uma psicologia, o que de fato não parece ser o caso. Nesse sentido, é importante notar que a busca por "aquilo que somos" não tem nos Aforismos... um peso ontológico tão decisivo quanto para a ética schopenhaueriana, pois é nesse contexto elucidado a partir da experiência, da reflexão sobre o caráter empírico, sendo especialmente nesse sentido que o ensaio se apresenta como algo à parte da doutrina principal do autor. Ele mesmo, como vimos, considera o tema do caráter adquirido menos relevante para a Ética do que para a vida, e se qualquer relação há aí, diz respeito àquilo que Aristóteles, referido já na primeira linha do primeiro capítulo, entendia como pertinente ao "saber prático", o saber racional sobre o mundo das ações. Assim, como reconhece o próprio Schopenhauer na Introdução, Aforismos... consiste em obra afastada do ponto de vista ético-metafísico, sequer pertencendo à sua filosofia propriamente dita, acrescenta ele 22 .

A importância da ontologia, contudo, reside em que oferece as bases teóricas para que a razão compreenda a impossibilidade de vir a ser o que não se é, pois esse saber não pode ser oferecido por psicologia alguma, por exemplo algum, por lei alguma, uma vez que essa impossibilidade, desconsiderada a ontologia, pareceria dizer respeito ao futuro para sempre incógnito e, assim, meramente "incerto". Seria um erro pensar possibilidade e impossibilidade segundo o tempo ao invés de segundo o ser. A propósito, o texto consiste em "Aforismos de sabedoria sobre a vida", ou ainda, respeitando-se o título original, "Aforismos sobre a sabedoria de vida"23. Desse modo, evitar-se-ia a interpretação indesejável de que a obra seja destinada à produção de um saber cujo fundamento só se pode reconhecer na própria experiência com o próprio caráter - vimos que mesmo o saber verdadeiro não tem por efeito certo sua efetivação no mundo da ação. Schopenhauer não está prescrevendo um modo de vida, mas testemunhando o que se pode aprender apenas vivendo, independentemente de teorizações éticas ou metafísicas. Afinal, a obra resulta $d a$ sabedoria de vida adquirida pelo autor que então escreve sobre ela.

A título de conclusão, retomando a citação inicial, compreende-se que o

\footnotetext{
${ }^{22}$ Cf. idem, ibidem, p. 2.

23 "Sobre a" traduz o alemão "zur", no sentido de assunto tratado, correspondendo ao latim "de". "Da sabedoria de vida" seria o bastante para se evitar ambiguidades.
} 
mundo em sua totalidade é o fenômeno universal da Vontade tal como se faz aparente no tempo e no espaço e, do mesmo modo, cada indivíduo é fenômeno singular de uma individualidade livremente determinada como tal a partir de si mesma na condição de uma possibilidade da Vontade que, como tal, poderia se efetivar ou não. "Ora, em conformidade à liberdade da Vontade, o objeto poderia não existir, ou originária e essencialmente ser algo inteiramente outro", afirma Schopenhauer no parágrafo inicial do $§ 55$ do MVR, mas, "uma vez lá e existente, o objeto [...] não pode ser outro, isto é, mudar, nem sair da série, isto é, desaparecer"24. Do ponto de vista não-temporal, essa individualidade se configura como um caráter inteligível, cuja inteligibilidade se torna a cada vez possível pela experiência. Na vida, contudo, o querer é, a princípio, errante, deixando-se levar por motivos nem sempre adequados às potencialidades originárias do indivíduo em questão. É justamente a descoberta de máximas adequadas ao caráter inalienável, irremissível e inamissível de que cada indivíduo é expressão fenomênica o que torna possível sair da errância e adquirir um caráter, ou seja, adotar princípios uniformes de conduta. É o que se lê quase ao fim do mesmo $§ 55$ :

[...] o mero querer e a mera habilidade em fazer não são suficientes em si mesmos, mas um homem também precisa saber o que quer, e saber o que pode fazer. Tão-somente assim mostrará caráter, para então poder consumar algo consistente. Antes que chegue a este ponto, apesar da consequência natural do caráter empírico, ainda é sem caráter; e, embora no todo permaneça fiel a si e siga o próprio caminho guiado por seu demônio interior, descreverá não uma linha reta, mas sim uma torta e desigual, hesitando, vagueando, voltando atrás, cultivando para si arrependimento e dor. Tudo porque nas grandes e pequenas coisas vê diante de si o tanto quanto é possível e alcançável pelo homem em geral, sem saber todavia qual parte de tudo isso é conforme à sua natureza, e realizável apenas por si, sim, fruível apenas por si. Dessa forma, a muitos invejará em virtude de posição e condição que, no entanto, convêm exclusivamente ao caráter deles, não ao seu, e nas quais se sentiria antes infeliz, até mesmo sem as conseguir suportar 25 .

Vale ainda observar que a noção de caráter adquirido não contradiz a doutrina da imutabilidade do caráter, pelo contrário! Se o caráter fosse mutável,

\footnotetext{
${ }^{24}$ SCHOPENHAUER, A. MVR I, § 55, p. 372.

${ }^{25}$ Idem, ibidem, p. 392-393; grifos meus.
} 
seria o mesmo que admitir que não se pode adquirir caráter algum, pois a experiência nada poderia nos ensinar de sólido a nosso próprio respeito, seria tudo mera fatalidade, mas fatalidade só diz respeito à origem da existência26. Pela sabedoria de vida, porém, adquirir racionalmente um caráter não significa outra coisa senão ser si mesmo. De todo modo, mesmo isso, é para poucos, conforme as palavras que encerram a Introdução a Aforismos...: "Em geral, os sábios de todos os tempos disseram sempre o mesmo, e os tolos, isto é, a imensa maioria de todos os tempos, sempre fizeram o mesmo, ou seja, o contrário; e assim continuará a ser"27. Que otimismo resta a quem sabe que nada pode ser melhor do que desde sempre pôde ser? Que pessimismo resta a quem, conhecedor da essência de todo mal, transcendeu para além de Maya? Um e outro... padecimentos de todos nós restantes, do purgatório habitantes, entre um e outro, ansiando pelo bem contra o mal; nada mais... nada menos. Entre o melhor e o pior dos mundos, apenas a vida... como ela é.

\section{Observações suplementares acerca de caráter e ânimo}

Na seção "Compaixão e virtude", fiz referência a ações praticadas "de bom coração". Essa bondade, que Schopenhauer hesita em denominar "boa vontade", embora chegue a dizer que remete a uma "bondade de caráter" (Güte des Charakters) - o que dá no mesmo -, é frequentemente associada a um certo “ânimo" (Gemüth). A propósito, é notável que a expressão "Güte des Charakters" ocorra apenas duas vezes em todo o MVR, uma em cada tomo ${ }^{28}$. Reserva-se a "Gemüth" uma série de disposições psicológicas, razão pela qual Eduardo Fonseca chega a vertê-la em português por "psiquismo" 29 no contexto em que se trata de humores que favorecem a sobreposição da vontade com relação ao intelecto, produzindo-se palavras ou ações precipitadas. Pode-se dizer que, dada a imutabilidade do caráter, a sabedoria de vida consistiria na capacidade de uma

\footnotetext{
26 "Fatalität” ocorre duas vezes no MVR II precisamente nesse sentido, nos capítulos 17 e 50.

${ }^{27}$ SCHOPENHAUER, A. Aforismos para a sabedoria de vida, p. 2.

${ }^{28}$ A primeira ocorrência é no $§ 67$ (p. 479), quando Schopenhauer discorre sobre o choro, que, segundo ele, sinalizando o retorno da compaixão ao seu ponto de partida, está "condicionado tanto pela capacidade de amar e compadecer-se quanto pela fantasia". A segunda ocorrência é no capítulo 19 , item 8 , onde a bondade de caráter é desvinculada da mera "falta de entendimento", o que significa que não há bondade na mera tolice (v. 1, p. 344).

${ }^{29}$ SCHOPENHAUER, A. MVR II(1), 19, p. 322.
} 
ordenação dos ânimos, para o que se faz evidentemente necessária a conquista de um equilíbrio entre os movimentos externos e internos, ou seja, a adequação que vimos corresponder à "aquisição de um caráter". Em outras palavras, a vontade se sobrepõe ao intelecto sempre que este não "funciona" no sentido de atendê-la adequadamente, de maneira que ser para consigo mesmo de acordo com o que se é e pode obter promove o que ordinariamente se denomina "contenção de ânimos", no sentido de que, segundo máximas apropriadas, não nos perturbamos por aquilo que está fora de nosso alcance. Aqui, "ânimo" e "caráter" entram em sintonia, adquirem uma uniformidade de disposição (Stimmung), não sendo por acaso que um dos significados da palavra "Gemüt" é, precisamente, "caráter". Trata-se do que é "natural" a um indivíduo, sua índole, ou personalidade, por assim dizer.

Considerando que a palavra "Gemüt" tem um sentido genericamente positivo, sendo as derivações negativas vinculadas a formas de "falta de caráter" "gemütlos", por exemplo, designa alguém "sem coração", "insensível" -, tal positividade parece conquistada mediante a referida sintonia entre sentimentos e o modo próprio de ser. Significa dizer que o sábio é precisamente aquele que, pela experiência refletida, consegue atingir uma boa disposição contendo sua impetuosidade e ansiedade em face do que não lhe cabe dominar, evitando-se assim que nossa própria natureza viole máximas racionais que lhe sejam impróprias - logo, vê-se aí o papel de Gemüt. 0 sábio é, em última análise, alguém bem-disposto e, nessa proporção, alegre (wohlgemut, frohgemut). Para tanto, é preciso, como vimos, certo esforço, coragem (Mut) na moderação de nossas representações que nos fazem agir e motivam de modo errático. Adquirir um caráter é, em última análise, dar a si mesmo uma disposição mais autêntica, mais apropriada a si mesmo.

Em sua tradução para $O$ conceito de angústia, de Kierkegaard, Álvaro Valls nos oferece, em nota, o seguinte extrato do dicionário etimológico Der Grossen Duden, volume 7, segundo o qual "Gemüt" designa "a unidade dos sentimentos e pensamentos do espírito, bem como o lugar dos sentimentos e pensamentos internos"30. No contexto da nota, Kierkegaard cita a Psychologie de Rosenkrantz e sua definição de "Gemüth" como "unidade de sentimento e autoconsciência"

${ }^{30}$ KIERKEGAARD, S. A. O conceito de angústia, IV, § 2.II, p. 153, n. 289; tradução minha. 
explicando "que o sentimento se apresent[a] na consciência de si e que, [reciprocamente,] o conteúdo d[a] consciência de si [é] sentido pelo sujeito como aquilo que é seu. Apenas esta unidade pode ser designada por [Gemüth]. Pois, se falta a clareza do conhecimento, o saber sobre o sentimento, então só existe o impulso [Drang] do espírito natural, a expansão da imediatidade. Mas se falta o sentimento, então só existe um conceito abstrato que não alcançou a interioridade última da existência espiritual, que não se tornou uma só coisa com o si mesmo (Selbst) do espírito"31. Não apenas Gemüt congrega em seu significado o que se alcança pela aquisição de caráter, segundo Schopenhauer, como, na análise de Rosenkrantz, encontramos a mesma afirmação de que, na falta de caráter, age-se erraticamente - pulsional, se se preferir -, e de que, de modo geral, o sentimento concreto é requisito para o agir consciente tanto quanto o saber sobre si mesmo é requisito para a ação bem disposta e ordenada. Os "impulsos naturais" da vontade só são moderáveis pela união de razão e sensibilidade e isto não significa algo de exterior ou friamente calculado, mas a aquisição de uma unidade consigo mesmo, um contato concreto e uma vivência do que Rosenkrantz denomina "die letzte Innigkeit des geistigen Daseins" em sua obra de 1837.

Seria de grande interesse desenvolver aqui a análise de Kierkegaard apoiada nas palavras ora citadas, à qual remeto o leitor, mas isso extrapolaria os limites convenientes de uma "observação suplementar" a um artigo cujo propósito, inclusive, não é o de confrontar Schopenhauer ao pensador dinamarquês. Todavia, permito-me encerrar com algumas palavras encontradas na referida análise, no simples intuito de justificar esse interesse. Diz Kierkegaard: "O Gemüth é uma determinação da imediatidade, enquanto que, em contrapartida, a seriedade é a originalidade conquistada do Gemüth, sua originalidade conservada na responsabilidade da liberdade, sua originalidade mantida no gozo da bemaventurança" 32 . E mais:

A seriedade neste sentido é a personalidade mesma, e só uma personalidade séria é uma personalidade efetiva [...], pois para fazer alguma coisa com seriedade se requer, acima de tudo e principalmente, que se saiba o que é objeto da seriedade. [...]

${ }^{31}$ ROSENKRANTZ apud KIERKEGAARD, ibidem, p. 153-154, na tradução de Valls, levemente alterada onde indicado.

${ }^{32}$ KIERKEGAARD, S. A., ibidem, p. 154. 
decerto pode-se nascer com um gênio próprio [Gemyt], mas não se nasce com seriedade. [Aquele objeto da seriedade] cada ser humano possui, pois é ele mesmo [...] ${ }^{33}$.

Nesse sentido, cumpre sugerir possíveis articulações entre a seriedade kierkegaardiana e a sabedoria de vida schopenhaueriana, bem como entre suas respectivas noções de "gênio próprio" e "caráter inteligível”, em cujos respectivos contextos podemos encontrar a rara possibilidade de um caráter empírico (Gemüt) conquistar sua originalidade; com ela e sua manutenção, assumir a responsabilidade da liberdade de ser o que se quis no gozo da maior bemaventurança possível.

\section{Referências bibliográficas}

KANT, I. Fundamentação da metafísica dos costumes. Trad. Paulo Quintela. Lisboa: 70, 2007.

KIERKEGAARD, S. A. O conceito de angústia. 3. ed. Trad. Álvaro Luiz Montenegro Valls. Petrópolis: Vozes; Bragança Paulista: EDUSF, 2013.

LEFRANC, J. Compreender Schopenhauer. 5. ed. Petrópolis: Vozes, 2011.

MORAES, D. O dualismo kantiano e sua crítica por Schopenhauer: considerações acerca do caráter analógico da filosofia prática e suas limitações. Princípios: Revista de Filosofia Publicação do Programa de Pós-Graduação em Filosofia da UFRN. Natal, v. 20, n. 33, jan.jun. 2013, p. 411-447. Disponível em: <http://www.periodicos.ufrn.br/principios/article/view/7525>. Acesso em: 15 out. 2015.

ROUSSEAU, J.-J. Do contrato social: ou princípios do direito político. Trad. Lourdes Santos Machado. São Paulo: Nova Cultural, 1997. (Coleção Os Pensadores).

RUSSELL, B. História da filosofia ocidental (livro 3.: A filosofia moderna - segunda parte: Desde Rousseau até o presente). São Paulo: Companhia Editora Nacional, 1967.

SCHOPENHAUER, A. Sobre o fundamento da moral. Trad. Maria Lúcia Mello Oliveira Cacciola. São Paulo: M. Fontes, 2001.

SCHOPENHAUER, A. O mundo como vontade e como representação. Tomo I. Trad. Jair Barboza. São Paulo: UNESP, 2005.

SCHOPENHAUER, A. Aforismos para a sabedoria de vida. Trad. Jair Barboza. 3. ed. São Paulo: M. Fontes, 2009.

${ }^{33}$ Idem, ibidem, p. 155-156. 
SCHOPENHAUER, A. O mundo como vontade e representação. Tomo II - Complementos. Trad. Eduardo Ribeiro da Fonseca. Curitiba: UFPR, 2014. 2 v.

Recebido: $19 / 11 / 15$

Received: 11/19/15

Aprovado: $25 / 02 / 16$

Approved: 02/25/16 